\title{
Perbedaan Derajat Aglutinasi Uji Golongan Darah Berdasarkan Teknik Penanganan Sampel dalam Pembuatan Suspensi Sel Darah Merah
}

\author{
Difference of Aglutination Degrees in Blood Grouping Test Based on Sample \\ Handling Techniques in Making Red Blood Suspension
}

\author{
Lucia Sincu Gunawan* \& Rumeyda Chitra Puspita \\ Program Studi D4 Analis Kesehatan \\ Fakultas Ilmu Kesehatan, Universitas Setia Budi Surakarta, \\ Jl. Let. Jend. Sutoyo, Mojosongo, Surakarta, 57127, Jawa Tengah, Indonesia \\ *Corresponding Author: sincugunawan@gmail.com
}

Received: July 4, 2019; Revise: December 5, 2019; Accepted:December 23, 2019

DOI : https://doi.org/10.31001/biomedika.v12i2.546

\begin{abstract}
ABSTRAK
Pemeriksaan laboratorium sebelum pemberian transfusi darah (pretransfusion testing) merupakan bagian yang sangat vital dalam kegiatan transfusi. Pada beberapa jenis uji pra transfusi membutuhkan suspensi sel darah merah. Pembuatan suspensi sel bertujuan untuk mengoptimalkan reaksi antigen-antibodi sehingga reaksi yang muncul dapat diamati dengan jelas. Praktek kerja penentuan golongan darah menggunakan suspensi sel darah merah, di mana dalam penyediaannya menggunakan fase pencucian yang memakan waktu. Jenis sampel yang digunakan dapat berupa whole blood dengan antikoagulan ataupun sampel darah beku. Karena keterbatasan waktu, maka modifikasi dilakukan pada prosedur baku. Penelitian ini bertujuan untuk mengetahui perbedaan derajat aglutinasi uji golongan darah berdasarkan teknik penanganan sampel dalam pembuatan suspensi sel darah merah. Uji golongan darah Cell Grouping metode tabung dilakukan pada sampel darah vena dengan teknik penanganan sampel yang berbeda yaitu, sampel darah beku tanpa antikoagulan dengan penyimpanan, sampel darah segar dengan langsung penambahan $\mathrm{NaCl} 0,9 \%$, dan sampel darah antikoagulan EDTA dengan penyimpanan dalam refrigerator $8-24$ jam dengan suhu $4^{\circ} \mathrm{C}$. Jumlah sampel untuk tiap jenis penanganan ada 30 sampel, dan dilakukan penilaian derajat aglutinasi pada uji golongan darah, dilakukan oleh 2 analis. Hasil mean derajat agutinasi dibedakan antara 3 teknik pembuatan suspensi dengan sampel $\mathrm{NaCl}(\mathrm{Mean}=3.88 ; \mathrm{SD}=$ 0.32), sampel beku (Mean= 3.93; $\mathrm{SD}=0.25$ ), dan sampel EDTA (Mean= 3.98; $\mathrm{SD}=0.13$ ), namun perbedaan mean tersebut secara statistik tidak signifikan ( $p>0.05)$, sehingga dapat disimpulkan ketiga jenis sampel bisa digunakan untuk menggantikan satu dengan lainnya sebagai alternatif sampel yang sebanding dalam pembuatan suspensi sel darah merah untuk menentukan golongan darah ABO metode cell grouping.
\end{abstract}

Kata kunci : golongan darah; suspensi sel darah merah; aglutinasi

\begin{abstract}
Pre transfusion testing is a very essential part of blood transfusion procedure. In some types of pretransfusion test, suspension of red blood cells is required. This cell suspension is made to optimize the antigen-antibody reaction so that the on going reaction can be clearly observed. The practice of determining blood type needs a suspension of red blood cells, which its washing phase is a timeconsuming. The type of sample used can be whole blood with anticoagulants or frozen blood samples. Due to time constraints, the standard procedures were modified. This study aimed to determine the differences in the degree of agglutination of blood type testing based on the handling samples' techniques in the manufacture of red blood cell suspensions. Blood group testing was done by the tube method on
\end{abstract}


venous blood samples with different sample handling techniques: frozen blood samples without anticoagulants with storage, fresh blood samples with direct addition of $0.9 \% \mathrm{NaCl}$, and EDTA anticoagulant blood samples with refrigerator storage $8-24$ hours at $4^{0} \mathrm{C}$. The number of samples for each type of treatment is 30 samples, and an assessment of the degree of agglutination in the blood group test is carried out by 2 analysts. There were differences in the mean degree of aglutination between the 3 suspensi-making techniques with $\mathrm{NaCl}$ samples (Mean = 3.88; $S D=0.32)$, frozen samples (Mean = 3.93; $S D=0.25)$, and EDTA samples (Mean $=3.98 ; S D=0.13)$, but the mean differences was not statistically significant ( $p>0.05)$, so it can be concluded that the three types of samples could be used to replace one another as a comparable sample alternative in making red blood cell suspension to measure ABO cell grouping method.

Keywords: blood type; red blood cell suspension; agglutination

\section{PENDAHULUAN}

Transfusi darah merupakan salah satu komponen terapi yang sangat penting dalam penatalaksanaan pasien. Pemberian transfusi darah harus berpegang pada prinsip bahwa manfaat yang akan diterima oleh pasien jauh lebih besar dibandingkan risiko yang akan ditanggung, sehigga semboyan "Getting the right blood the right patient at the right time and right place" harus benar-benar dilaksanakan (Mulyantari, 2017).

Pemeriksaan laboratorium sebelum pemberian transfusi darah (pretransfusion testing) merupakan bagian yang sangat vital dalam kegiatan transfusi. Uji pratransfusi inilah yang menentukan apakah produk darah yang akan ditransfusikan dapat memberikan manfaat yang optimal atau tidak kepada pasien. Selain itu, uji pratransfusi juga dapat memprediksi apakah transfusi akan memberikan efek samping yang fatal atau tidak sehingga pencegahan terjadinya efek samping pemberian transfusi dapat lebih awal dilakukan. (Mulyantari, 2017)

Pada beberapa jenis uji pratransfusi membutuhkan suspensi sel darah merah. Pemuatan suspensi sel bertujuan untuk mengoptimalkan reaksi antigen-antibodi sehingga reaksi yang muncul dapat diamati dengan jelas. Beberapa kepustakaan menyebutkan bahwa suspensi sel 3\% banyak dipakai untuk pemeriksaan serologi. Namun, berdasarkan Word Health Organization, suspensi sel 5\% umum dipakai untuk prosedur serologi (WHO, 2013).

Pemeriksaan golongan darah adalah suatu prosedur laboratorium yang dilakukan untuk menentukan jenis golongan darah. Pada uji pratransfusi, pemeriksaan golongan darah minimal yang harus dikerjakan adalah golongan darah sistem ABO dan Rhesus (D typing). Pemeriksaan golongan darah dilakukan baik pada donor maupun pada pasien (WHO, 2002).

Aglutinasi sel darah merah dalam pemeriksaan golongan darah dapat berlangsung melalui dua tahapan. Tahap pertama antibodi berikatan dengan permukaan sel darah merah, tahap kedua antibodi berinteraksi dengan sel darah merah sehingga sel-sel saling berdekatan dan terjadilah aglutinasi. Tahap pertama aglutinasi dipengaruhi oleh suhu, $\mathrm{pH}$ medium, konstanta afinitas antibodi, waktu atau lama inkubasi, kekuatan ion pada 
medium, dan rasio antigen antibodi. Tahap kedua aglutinasi dipengaruhi oleh jarak antar sel, muatan molekul dalam suspensi, deformitas membran, molekul permukaan membran dan struktur molekul (Mulyantari, 2017).

Secara garis besar, penyebab ketidaksesuaian golongan darah terbagi menjadi dua yaitu kesalahan teknis dan permasalahan pada sampel baik sampel eritrosit maupun serum atau plasma. Sumber discrepancy dari kesalahan teknis antara lain kesalahan identifikasi dan dokumentasi, kesalahan pada reagen dan peralatan, seperti quality control reagen tidak dilakukan dengan baik, reagen terkontaminasi dan hemolisis, waktu sentrifugasi tidak tepat atau peralatan tidak dikalibrasi dengan teratur dan kesalahan pada Standard Operating Procedure (SOP), seperti prosedur tidak sesuai dengan instruksi dari pabrik reagen, penambahan reagen atau sampel yang tidak tepat, konsentrasi suspensi sel darah merah tidak tepat, endapan sel pada bagian bawah tersuspensi secara komplit sebelum derajat aglutinasi ditentukan (Blaney and Howard, 2013).

Pada praktek kerja pendidikan analis kesehatan salah satu kompetensi yang harus dimiliki adalah penentuan golongan darah. Dalam pelaksanaannya, maka ketersediaan alat, bahan, kecukupan waktu dan jumlah mahasiswa dalam setiap kegiatan praktek di laboratorium akan menentukan berhasil terlaksananya prosedur kerja yang telah ditetapkan dan pada akhirnya berpengaruh terhadap validitas pemeriksaaan. Praktek kerja penentuan golongan darah menggunakan suspensi sel darah merah, dimana dalam penyediaannya menggunakan fase pencucian yang memakan waktu. Jenis sampel yang digunakan dapat berupa whole blood dengan antikoagulan ataupun sampel darah beku. Karena keterbatasan waktu, maka beberapa prosedur baku dilakukan modifikasi. Modifikasi ini menimbulkan pertanyaan apakah akan berpengaruh terhadap validitas pemeriksaaan golongan darah, sekaligus harus dipertimbangkan pembiasaan kerja praktek yang benar akan menimbulkan memori yang mendalam bagi calon tenaga analis kesehatan, sehingga di kemudian hari dapat merupakan acuan kerja di dunia kerja yang sesungguhnya. Tujuan Penelitian ini adalah untuk mengetahui perbedaan derajat aglutinasi uji golongan darah berdasarkan teknik penanganan sampel dalam pembuatan suspensi sel darah merah. Penelitian yang sejenis ini hanya menggunakan perbedaan sel darah yang dicuci dan tidak ataupun menggunakan beberapa jenis suspense dengan konsentrasi yang berbeda, yang menekankan pada penanganan sampel, sedangkan pada penelitian ini diteliti selain aspek penanganan sampel juga penyimpanan sampel.

\section{METODE PENELITIAN}

\section{Alat dan Bahan}

Alat yang digunakan sebagai berikut; tabung reaksi, centrifuge, spuit, mikropipet, refrigerator, kapas, plester, tip, termometer dan tourniquet. Bahan yang digunakan sebagai berikut; 
suspensi sel darah merah 5\%, antisera

A, antisera $\mathrm{B}, \mathrm{NaCl} 0,9 \%$

\section{Obyek Penelitian}

Obyek dalam penelitian ini adalah darah vena yang diambil dengan spuit pada vena di fossa cubiti. Sampel pada penelitian ini sejumlah 30 sampel darah vena yang diambil 2 kali pada hari 1 dan hari 2 pada probandus yang sama. Teknik pengambilan sampel dengan metode quota sampling. Dikelompokkan dalam tiga kelompok yaitu:

a. Sampel darah beku dengan penundaan waktu (A) adalah sampel darah vena yang tidak menggunakan

antikoagulan, disimpan dalam refrigerator dengan suhu $4^{\circ} \mathrm{C}$ selama $8-24$ jam.

b. Sampel darah lengkap segar (B) adalah sampel darah vena tanpa menggunakan

antikoagulan, dan langsung dicampur dengan $\mathrm{NaCl}$ yang telah disiapkan sebelumnya, berumur kurang dari 6 jam.

c. Sampel darah lengkap dengan penundaan waktu (C) adalah sampel darah vena dengan antikoagulan EDTA, disimpan dalam refrigerator dengan suhu $4^{\circ} \mathrm{C}$ selama $8-24$ jam.

\section{Prosedur Penelitian}

\section{Pengambilan darah vena}

1. Menyiapkan alat-alat yang diperlukan : Spuit, kapas alkohol $70 \%$, tali pembendung (torniquete), plester, tabung reaksi

2. Memasang jarum pada holder, dipastikan terpasang erat.

3. Melakukan pendekatan pasien dengan tenang dan ramah; diusahakan pasien senyaman mungkin.

4. Mengidentifikasi pasien dengan benar sesuai dengan data dilembar permintaan.

5. Memverifikasi keadaan pasien, misalnya puasa atau konsumsi obat. dicatat bila pasien minum obat tertentu, tidak puasa dsb.

6. Meminta pasien untuk meluruskan lengannya, dipilih lengan yang banyak melakukan aktivitas.

7. Meminta pasien mengepalkan tangan.

8. Memasang turniquete kira-kira $10 \mathrm{~cm}$ di atas lipat siku.

9. Memilih bagian vena mediana cubital atau cephalic. melakukan perabaan (palpasi) untuk memastikan posisi vena; vena teraba seperti sebuah pipa kecil, elastis dan memiliki dinding tebal.

10. Membersihkan kulit pada bagian yang akan diambil dengan kapas alkohol $70 \%$ dan dibiarkan kering. Kulit yang sudah dibersihkan jangan dipegang lagi. 
11. Menusuk bagian vena dengan posisi lubang jarum menghadap ke atas.

12. Menghisap darah secara pelanpelan dan sampai dicapai volume yang diperlukan

13. Melepas tourniquet dan meminta pasien membuka kepalan tangannya. Jangan menarik jarum sebelum tourniquet dibuka.

14. Meletakkan kapas ditempat suntikan lalu segera melepaskan/menarik jarum. Menekan kapas beberapa saat lalu diplester selama kira-kira 15 menit.

\section{Penanganan sampel}

1. Sampel darah beku dengan penundaan waktu (A). Sampel darah vena yang didapat, dimasukkan ke dalam tabung melalui dinding tabung dimana pada tabung tidak ditambahkan antikoagulan, kemudian disimpan dalam refrigerator dengan suhu $4^{\circ} \mathrm{C}$ selama $8-24$ jam. Pisahkan serum, sebelum pencucian sel.

2. Sampel darah lengkap segar (B). Sampel darah vena yang didapat dan berumur kurang dari 6 jam, sebanyak $0,5 \mathrm{~mL}$ dimasukkan ke dalam tabung berisi $\mathrm{NaCl} 0,9 \%$ yang telah disiapkan sebelumnya, kurang lebih mengisi tigaperempat tabung (bagian dari tahap pencucian sel darah merah).

3. Sampel darah lengkap dengan penundaan waktu (C). Sampel darah vena ditambahkan dengan antikoagulan EDTA sebanyak 1 $\mathrm{mg} / 1 \mathrm{~mL}$ darah, dihomogenkan dengan baik dan disimpan dalam refrigerator dengan suhu $4^{\circ} \mathrm{C}$ selama $8-24$ jam.

\section{Pencucian sel}

Pencucian sel darah merah bertujuan untuk mendapatkan sel darah merah yang bebas dari protein/ globulin yang dapat mengganggu pemeriksaan serologi. Prosedur pencucian sel sebagai berikut:

1. Setengah mili liter darah pekat dimasukkan ke dalam tabung kemudian tambahkan larutan salin/ Natrium Clorida 0,9\% sampai mengisi $3 / 4$ bagian tabung.

2. Lakukan sentrifugasi dengan kecepatan 3000 rpm selama 1 menit dan buang seluruh supernatant.

3. Lakukan pencucian sebanyak 3 kali dan buang seluruh supernatan pada akhir pencucian, sehingga hasil akhirnya adalah sel darah merah yang sudah dicuci (Mulyantari, 2017).

\section{Pembuatan suspensi darah merah}

1. Pembuatan suspensi sel bertujuan untuk mengoptimalkan reaksi antigen-antibodi sehingga reaksi yang muncul dapat diamati dengan jelas. Berdasarkan WHO, suspensi sel $5 \%$ umum dipakai untuk prosedur serologi (WHO, 2013).

2. Berikan label pada tabung sampel, teteskan 1 tetes sel darah merah yang sudah dicuci 
tambahkan 19 tetes $\mathrm{NaCl} 0,9 \%$ dan homogenkan.

\section{Pemeriksaan golongan darah cell grouping dengan metode tube}

1. Teteskan 1 tetes anti-A pada tabung yang bersih dan kering, berikan label pada tabung.

2. Teteskan 1 tetes anti-B pada tabung yang bersih dan kering, terpisah dari tabung pertama kemudian berikan label pada tabung.

3. Teteskan 1 tetes anti-AB pada tabung ketiga (tergantung rekomendasi reagen yang digunakan)

4. Tambahkan pada masingmasing tabung 1 tetes suspensi sel darah merah 5\%

5. Campur dengan baik kemudian lakukan sentrifugasi dengan kecepatan $1000 \mathrm{rpm}$ selama 1 menit

6. Resuspensi dengan baik sel yang mengendap pada dasar tabung, lihat ada tidaknya aglutinasi

7. Baca dan interpretasi hasil serta lakukan pencatatan hasil reaksi pada semua tabung.

\section{Interpretasi hasil}

Interpretasi hasil uji golongan darah yaitu derajat kekuatan aglutinasi sel darah merah, yang menandakan terjadinya reaksi antigen dan antibodi yang dapat diamati baik secara makroskopik maupun mikroskopik.

-4+ : terdapat satu gumpalan besar

- 3+ : terdapat 2 atau 3 gumpalan

-2+ : sejumlah gumpalan kecil dengan supernatan yang jernih
-1+ : sejumlah gumpalan kecil dengan supernatan yang keruh

- Negatif : suspensi sel halus

- Hemolisis: hemolisis parsial atau komplit, menunjukkan reaksi positif, dianggap sama dengan 4+

Pembacaan hasil dilakukan oleh dua analis kesehatan, dimana pembacaan dilakukan secara mandiri dan dicatat pada lembar yang berbeda, pada waktu yang sama.

\section{HASIL DAN PEMBAHASAN}

Sampel darah yang berasal dari mahasiswa sejumlah 30 sampel yang memenuhi kriteria penelitian yaitu sampel mencukupi dari volume, tidak lisis dan memenuhi standar penanganan dan penyimpanan sampel. Pada proses pengambilan sampel terdapat beberapa kendala dalam penelitian ini, yaitu vena yang sulit diakses dan jumlah volume darah yang tidak sesuai, sedangkan pada penanganan dan penyimpanan sampel didapatkan penyulit yaitu adanya sampel yang beku dan lisis, sehingga tidak memenuhi syarat sampel. Tidak semua mahasiswa mengetahui golongan darahnya, dan penelitian ini juga dapat memberikan informasi golongan darah mahasiswa yang menjadi subyek penelitian, meski demikian pada metode cell grouping penentuan golongan darah $\mathrm{ABO}$, maka golongan darah $\mathrm{O}$ tidak akan menghasilkan aglutinasi baik pada antisera A dan antisera B, sehingga sampel darah dengan golongan darah $\mathrm{O}$ tidak dapat digunakan dalam penelitian ini. 
Dari tabel 4.1 dapat dilihat, 30 sampel yang memenuhi syarat, yang sudah disiapkan dalam 90 tabung sesuai dengan perlakuan dalam pembuatan suspensi sel darah merah, yaitu tabung A1 untuk sampel subyek nomer 1 dimana sampel darah beku dan disimpan dalam refrigerator, B1 untuk sampel subyek nomer 1 dimana sampel darah segar yang langsung dimasukkan dalam tabung berisi $\mathrm{NaCl} 0,9 \%$, tabung C1 untuk sampel subyek nomer 1 dimana sampel darah dengan antikoagulan EDTA disimpan dalam refrigerator, dan seterusnya dilakukan pembuatan suspensi darah dan pemeriksaan golongan darah.

Tabel 4.1 Hasil Uji Golongan Mahasiswa

\begin{tabular}{|c|c|c|c|c|c|c|c|}
\hline \multirow{2}{*}{ No. } & \multirow{2}{*}{$\begin{array}{c}\text { Golongan } \\
\text { Darah }\end{array}$} & \multicolumn{2}{|c|}{ Sampel beku } & \multicolumn{2}{|c|}{$\begin{array}{c}\text { Sampel segar + } \\
\mathrm{NaCl}\end{array}$} & \multicolumn{2}{|c|}{$\begin{array}{c}\text { Sampel } \\
\text { EDTA }\end{array}$} \\
\hline & & 1 & 2 & 1 & 2 & 1 & 2 \\
\hline 1 & $\mathrm{~A}$ & 4 & 4 & 4 & 4 & 4 & 4 \\
\hline 2 & B & 4 & 4 & 4 & 4 & 4 & 4 \\
\hline 3 & B & 4 & 4 & 4 & 4 & 4 & 4 \\
\hline 4 & B & 3 & 3 & 4 & 4 & 4 & 4 \\
\hline 5 & A & 4 & 4 & 4 & 4 & 4 & 4 \\
\hline 6 & A & 4 & 4 & 4 & 4 & 4 & 4 \\
\hline 7 & B & 4 & 4 & 4 & 4 & 4 & 4 \\
\hline 8 & B & 4 & 4 & 4 & 4 & 4 & 4 \\
\hline 9 & B & 4 & 4 & 4 & 4 & 4 & 4 \\
\hline 10 & B & 4 & 4 & 4 & 4 & 4 & 4 \\
\hline 11 & B & 4 & 4 & 4 & 4 & 4 & 4 \\
\hline 12 & B & 4 & 4 & 4 & 4 & 4 & 4 \\
\hline 13 & B & 4 & 4 & 4 & 4 & 4 & 4 \\
\hline 14 & B & 4 & 4 & 4 & 4 & 4 & 4 \\
\hline 15 & $\mathrm{AB}$ & 4 & 4 & 4 & 4 & 4 & 4 \\
\hline 16 & B & 4 & 4 & 4 & 3 & 4 & 4 \\
\hline 17 & A & 4 & 4 & 4 & 4 & 4 & 4 \\
\hline 18 & A & 4 & 4 & 4 & 4 & 4 & 4 \\
\hline 19 & B & 4 & 4 & 4 & 4 & 4 & 4 \\
\hline 20 & $\mathrm{AB}$ & 4 & 4 & 4 & 4 & 4 & 4 \\
\hline 21 & A & 4 & 4 & 4 & 4 & 4 & 4 \\
\hline 22 & B & 4 & 3 & 4 & 3 & 4 & 3 \\
\hline 23 & B & 4 & 4 & 4 & 4 & 4 & 4 \\
\hline
\end{tabular}




\begin{tabular}{lcllllll}
24 & B & 4 & 4 & 3 & 3 & 4 & 4 \\
25 & B & 4 & 4 & 3 & 3 & 4 & 4 \\
26 & B & 4 & 3 & 4 & 3 & 4 & 4 \\
27 & A & 4 & 4 & 4 & 4 & 4 & 4 \\
28 & B & 4 & 4 & 4 & 4 & 4 & 4 \\
29 & AB & 4 & 4 & 4 & 4 & 4 & 4 \\
30 & A & 4 & 4 & 4 & 4 & 4 & 4 \\
\hline
\end{tabular}

Hasil intepretasi uji golongan darah dilakukan oleh 2 analis. Uji korelasi antara dua analis untuk mengetahui korelasi hasil pengamatan derajat aglutinasi golongan darah, diharapkan korelasi yang baik antara 2 analis dalam mengamati derajat aglutinasi dapat dilihat pada tabel 4.2. Interpretasi hasil dari tabel 4.2 yaitu terdapat korelasi yang cukup kuat dalam pengamatan derajat aglutinasi antara analis 1 dan analis 2, dan korelasi tersebut secara statistik signfikan ( $\mathrm{r}=$ 0.56; p <0.001). Dapat disimpulkan terdapat kesepakatan yang cukup baik antara kedua pengamatan tersebut.

Tabel 4.2 Korelasi Antara Hasil Pengamatan Derajat Aglutinasi Antara Analis 1 Dan Analis 2

\begin{tabular}{cccc}
\hline Analis & $\mathbf{n}$ & Koefisien Korelasi (r) & $\mathbf{p}$ \\
\hline Analis 1 & 90 & 0.56 & $<0.001$
\end{tabular}

Analis 2

Tabel 4.3 menunjukkan terdapat perbedaan Mean derajat agutinasi antara 3 teknik pembuatan suspensi dengan sampel $\mathrm{NaCl}(\mathrm{Mean}=3.88 ; \mathrm{SD}=0.32)$, sampel beku $(\mathrm{Mean}=3.93 ; \mathrm{SD}=0.25)$, dan sampel EDTA (Mean= 3.98; $\mathrm{SD}=$ 0.13), namun perbedaan mean tersebut secara statistik tidak signifikan
( $\mathrm{p}>0.05)$. Dapat disimpulkan ketiga sampel bisa digunakan untuk menggantikan satu dengan lainnya sebagai alternatif sampel yang sebanding untuk mengukur derajat aglutinasi golongan darah ABO metode cell grouping.

Tabel 4.3 Perbedaan Mean Derajat Aglutinasi Antara 3 Teknik: NaCl, Beku, Dan EDTA (Diuji Dengan Oneway Anova)

\begin{tabular}{lllll}
\hline Metode & n & Mean & SD & p \\
\hline $\mathrm{NaCl}$ & 60 & 3.88 & 0.32 & 0.090 \\
$\mathrm{Beku}$ & 60 & 3.93 & 0.25 & \\
EDTA & 60 & 3.98 & 0.13 & \\
\hline
\end{tabular}


Tabel 4.4 menunjukkan terdapat perbedaan mean derajat agutinasi yang sangat kecil antara pasangan-pasangan sampel $\mathrm{NaCl}$, sampel beku, dan sampel EDTA, dan perbedaan mean tersebut secara statistik tidak signifikan
( $\mathrm{p}>0.05)$. Dapat disimpulkan ketiga sampel bisa menggantikan satu dengan lainnya sebagai alternatif yang sebanding untuk mengukur derajat aglutinasi.

Tabel 4.4 Perbedaan Mean Derajat Aglutinasi Pasangan Sampel, Antara Tiga Sampel: NaCl, Beku, Dan EDTA (Diuji Post-Hoc Test Bonferoni)

\begin{tabular}{llll}
\hline Sampel 1 & Sampel 2 & Beda Mean & p \\
\hline $\mathrm{NaCl}$ & Beku & 0.05 & 0.545 \\
$\mathrm{NaCl}$ & EDTA & 0.10 & 0.090 \\
$\mathrm{Beku}$ & EDTA & 0.05 & 0.545 \\
\hline
\end{tabular}

Tabel 4.3 perbedaan
derajat aglutinasi
penanganan dan penyimpanan dapat menjawab pertanyaan perbedaan derajat aglutinasi dalam penentuan golongan darah dengan jenis sampel yang berbeda. Meskipun adanya penyulit pada penelitian di awal, hal tersebut dapat menjadikan masukan dalam praktek kerja sehari-hari di laboratorium hematologi bahwa penyimpanan sampel di refrigerator, harus betul memperhatikan suhu, sehingga tidak merusakkan sampel yang disimpan di dalamnya. Pengukuran suhu yang menggunakan termometer sederhana yang diletakkan dalam refrigerator, hanya sebagai alat ukur yang dapat membantu dalam proses monitoring, tetapi tanpa adanya alarm yang memberikan informasi adanya ketidaksesuaian suhu yang diinginkan, termometer tak lagi dapat membantu dalam usaha pencegahan kerusakan bahan pemeriksaan. Suhu refrigerator dipengaruhi dari pengaturan suhu, jumlah barang yang disimpan, luas regrigerator, suhu ruangan dan frekuensi buka tutup pintu refrigerator. Proses penyimpanan sampel, merupakan salah satu faktor praanalitik yang harus diperhatikan analis dalam usaha menjamin validitas pemeriksaan. Perbedaaan sampel dalam pembuatan suspensi sel darah merah dalam penelitian ini tidak mempengaruhi derajat aglutinasi uji golongan darah $\mathrm{ABO}$, sehingga ketiga sampel ini dapat dipergunakan dalam pembuatan suspensi darah.

Pemilihan sampel ini dapat merujuk kebutuhan tiap laboratorium yang menyelenggarakan pemeriksaan, dimana sesuai standar operasional yang ditetapkan sebelumnya penggunaan darah segar langsung dicampurkan dengan $\mathrm{NaCl} \quad 0,9 \%$ yang telah dipersiapkan sebelumnya, masih sangat memungkinkan dikerjakan pada laboratorium dan mengandalkan tenaga analis yang terampil dalam praktek kerja. Pada laboratorium pendidikan, dimana mahasiswa membutuhkan waktu lebih lama dalam pengambilan sampel, maka alternatif penggantian 
jenis sampel dalam pembuatan suspensi sel darah merah merupakan salah satu solusi yang memungkinkan.

Tabel 4.3 menunjukkan terdapat perbedaan mean derajat agutinasi antara 3 teknik pembuatan suspensi dengan sampel $\mathrm{NaCl}(\mathrm{Mean}=3.88 ; \mathrm{SD}=0.32)$, sampel beku $(\mathrm{Mean}=3.93 ; \mathrm{SD}=0.25)$, dan sampel EDTA (Mean= 3.98; $\mathrm{SD}=$ 0.13), namun perbedaan mean tersebut secara statistik tidak signifikan $(\mathrm{p}>0.05)$ sehingga dapat disimpulkan ketiga sampel bisa digunakan untuk menggantikan satu dengan lainnya sebagai alternatif sampel yang sebanding untuk mengukur derajat aglutinasi golongan darah $\mathrm{ABO}$ metode cell grouping. Sebuah metode pemeriksaan akan lebih menguntungkan jika lebih sederhana, tidak memakan waktu, bisa lebih fleksibel dalam pengaturan waktu, dan tidak memakan biaya yang besar dengan penggunaan bahan-bahan seperti antikoagulan dan sebagainya. Meski demikian pemilihan sampel juga dapat terkait dengan rangkaian pemeriksaan yang harus dilakukan oleh pasien, semisal pasien membutuhkan pemeriksaan darah rutin dan juga uji golongan darah, maka sediaan darah dengan antikoagulan EDTA menjadi sebuah pilihan, sedangkan jika permintaan uji golongan darah ini dilakukan dimana sampel yang tersedia sampel darah beku dengan penyimpanan 24 jam tetap masih dapat digunakan, tanpa khawatir bahwa hasil pemeriksaan akan terpengaruh.

\section{KESIMPULAN}

Mean derajat aglutinasi antara 3 teknik pembuatan suspensi dengan sampel $\mathrm{NaCl}$ (Mean=3.88; $\mathrm{SD}=0.32$ ), sampel beku $(\mathrm{Mean}=3.93 ; \mathrm{SD}=0.25)$, dan sampel EDTA (Mean= 3.98; $\mathrm{SD}=$ 0.13 ), namun perbedaan mean tersebut secara statistik tidak signifikan ( $>0.05$ ), sehingga dapat disimpulkan ketiga jenis sampel bisa digunakan untuk menggantikan satu dengan lainnya sebagai alternatif sampel yang sebanding dalam pembuatan suspensi sel darah merah untuk mengukur derajat aglutinasi golongan darah $\mathrm{ABO}$ metode cell grouping.

\section{DAFTAR PUSTAKA}

Blaney, K. and Howard, P. 2013. Basic \& Applied Concepts of Blood Banking and Transfusion Practices 3rd Edition. Tissue Typing Laboratory, Florida Hospital; OneBlood, Inc., Orlando, Florida.

Handono, J., Wijaya, S.K., Ibrahim, A.S. 2017. Deteksi Aglutinasi Secara Otomatis Untuk Uji Golongan Darah Tipe ABO Berbasis Kertas. Jurnal Sains dan Teknologi. 1(1):15-25.

Kiswari, R. 2014. Hematologi dan Transfusi. Jakarta: PT. Gelora Aksara Pratama

Mulyantari, N.K., Yasa W.P.S. 2017. Laboratorium Pra Transfusi Up Date. Bali: Udayana University Press.

Mutiawati, V.K., 2013. Perbedaan Derajat Aglutinasi Pemeriksaan Golongan Darah Antara Eritrosit Tanpa Pencucian dengan Pencucian pada Penderita Talasemia. Jurnal Kedokteran Syiah Kuala. (2): 65-70.

NIB. 2013. Guidance Manual on ABO and Rh Blood Grouping. India: Ministry Of Health and Family Welfare.

Riyanto A. 2011. Aplikasi Metodologi Penelitian Kesehatan. Bantul: Nuha Medika. 
196 | Gunawan, L.S \& Puspita R.C.

Riswanto. 2013. Pemeriksaan Laboratorium Hematologi. Yogyakarta: Alfa Media \& Kana Medika.

Sukorini, U., Nugroho, D.K., Rizki, M.. 2010.

Pemantapan

Mutu

Internal
Jurnal Biomedika 12 (2): 187-196, September 2019

Laboratorium Klinik. Yogyakarta: Alfa Media \& Kana Medika.

WHO. 2002. Detection and Identification of Antibodies. Safe Blood and Blood Product. Genewa : WHO. 